\title{
Russia's 2020 Constitutional Reform: The Politics of Institutionalizing the Status-Quo
}

\author{
William E. Pomeranz \\ Deputy Director, Kennan Institute, Wilson Center, Washington, DC, USA \\ William.Pomeranz@wilsoncenter.org \\ Regina Smyth | ORCID: 0000-0002-4241-7932 \\ Professor, Department of Political Science, The College of Arts + Science, \\ Indiana University, Bloomington, IN, USA \\ rsmyth@indiana.edu
}

\begin{abstract}
The articles in this issue explore the longer-term implications of Russia's 2020 Constitutional Reform process. Assessing constitutional change from different theoretical and empirical approaches, these authors find that the constitution largely codified the status-quo as it had evolved over the past decade. The resulting institutional changes solidified the personalist political system that concentrates power in one leader. These reforms also created new mechanisms to preclude elite defection and generate societal quiescence. At the same time, the three-staged reform process that included formal adoption, national vote, and legal reconciliation, introduced new political risk by raising societal expectations, reinforcing cleavages through patriotic legitimization strategies, introducing new rigid structures, and relying on personalism and networks over institutional governance. These risks do not predict state failure but they suggest new challenges that will continue to shape Russian political development.
\end{abstract}

\section{Keywords}

constitutional reform - personalism - elite defection - governance 
Between January and July 2020, much of the discussion of Russia's constitutional reform focused on its implications for President Vladimir Putin's political fate. The new constitutional structure includes a provision that would "zero out" Putin's political history and allow him to evade term limits, and if re-elected, to remain in office until 2036. The new governing structures also offer Putin an alternative position: a strong non-elected position as Chairman of the newly defined State Council. This flexibility is a hallmark of the Putin regime: the capacity to adjust if the political context precludes a predictable path. Yet, while provisions are critical for Russia's political future, they are also just a small part of the changes that were introduced in 206 amendments to 41 articles, and five new articles.

Our idea for this special issue emerged in Fall 2020 just as the presidential administration, government and parliament began work on the process of reconciling the new constitution with existing legislation and governance practices. We asked a handful of scholars, who have written extensively on different aspects of Russian politics, to look beyond the nullification provision to explore broader implications of the reform. We posed several questions. Why introduce reform in 2020 and why invoke the national plebiscite along with formal procedures? If we examine the amendments through different substantive and theoretic lenses, which reforms seem most consequential? What are the implications of these changes for Russian political development over the longer-term?

These authors present broad agreement argued from very different perspectives. They universally argue that these changes largely codify existing practices rather than introduce new procedures, reinforcing a personalist system in which power is increasingly concentrated in the president and Putin himself is protected by the system. Yet, they also argue that the reforms are significant because they introduce new mechanisms to ensure elite and popular loyalty that limit flexibility, create new challenges, and influence regime capacity to affect political and economic modernization.

The speed in which the new constitution took shape suggests that Putin knew where he was heading despite all the drama associated with his sudden announcement in the state-of-the-nation address, the resignation of Prime Minister Medvedev, the nullification amendment, and the plebiscite. Most of these authors point to the 2021-2024 electoral cycle as a catalyst for rapid change, with the primary focus on the constraint of term limits. As Fabian Burkhardt 
points out, President Putin had degraded the meaning of term limits in his informal bargain with Dmitry Medvedev, invoking the "tandem" arrangement in 2008 in which he relinquished the presidency but remained as Prime Minister, and the castling or rokirovka in 2012. This meaning of these limits was further obscured in this process, and resolved only in terms of Putin's political future.

While the solution to the proximate problem would have been to eliminate terms limits, the Kremlin engaged in a complex process of bottom-up input, parliamentary voting, and the national vote. These authors argue that the multi-staged reform process served to generate elite and societal buy-in that would confirm a concentration of power in the President. Ben Noble and Nikolay Petrov show that this process continued through the third stage of the institution project: allowing social actors to participate in the process of reconciling the legal system with the constitutional changes while undermining formal checks and balances on the executive. Importantly, the process also eliminated pressures derived from President Putin's lame duck status, ensuring short-term coordination around the president.

Writing from different perspectives, Paul Goode and Smyth and Wilson Sokhey show that the extended process worked similarly for societal actors, who were allowed input into the nature of changes, and turned out to vote in the confirmatory plebiscite. Paul Goode underscores the role of societal engagement and regional assemblies in the Working Group that defined the conception of patriotism in the new constitution. By creating political space for voice and incorporating promises of long-demanded social protections, the Kremlin generated a form of authoritarian responsiveness. The national vote sealed this commitment through formal consultation which created buy-in to the reform project.

The politics of process did not end with the vote on July 1 but continued through 2020 with the passage of new legislation implementing the constitutional amendments. As Noble and Petrov show, the constitutional debate resulted in a major overhaul of Russian law and legal institutions. The hope, however, of a new distribution of power foreshadowed in Putin's original speech to the joint houses of parliament - such as an enhanced legislative branch-never materialized as new linkages across the bi-cameral legislature and government undermine the nature of checks and balances.

\section{$2 \quad$ Reconciling Institutions and Practice}

Putin's inevitable victory, however, does not mean that the constitutional amendment process should be dismissed as inconsequential. The decision to 
enact an extensive reform created a significant set of changes that alter powerrelationships at the national level and in federal relations, constrain the policy process, and redefine the bargain that underpins state-society relations. The 1993 constitution has now been significantly revised, although in a way that produces less, not greater, internal consistency and clarity.

William Pomeranz focuses on these new contradictions, especially the elevation of social rights over civil liberties. Ivan Grigoriev describes a diminished Constitutional Court that has now fallen under the sway of the presidential administration and personalist networks. Fabian Burkhart, effectively describes new constraints on federal institutions promulgated through their new interdependence and a horizontal system of checks and balances that enhance presidential power. The amendments eliminate independent local government, create a new power vertical (the unified system of public power), revitalize the State Council, and restore the procuracy's constitutional right to supervise the implementation of Russia's highest law. Vladimir Gel'man argues that these changes will cement historical practices of bad-governance, resulting in an even more incoherent state than existed to this point. As such, institutional change continues the practice of balancing political stability against the rule of law.

Still, despite the magnitude of these changes, none of them are surprising. Indeed, as several authors demonstrate, Russian law has been pursuing all of these objectives for years, using informal strategies that conflicted with formal institutional incentives. This approach comports to Dmitry Peskov's argument (quoted in Gel'man's article) that the goal of reform was to avoid radical changes. These amendments simply formalize what has been long-term practice across issue areas, federal levels, and institutional forms.

\section{Constitutional Reform and the Modernization Program}

One should not underestimate the resilience of the Russian state and its ability to survive a crisis, especially with a consistent source of revenue from energy exports. Yet, these authors argue that this is not a modernizing constitution but a constitution most likely to result in political stagnation, excessive centralization, increased social grumbling, and heightened top-down authoritarian rule. As Vladimir Gelman skillfully argues, the new constitution provides few incentives to prioritize development over politics. Across the board, these authors underscore that new institutional reforms provide limited incentives for autonomous action, innovation or attention to modernization. 
Yes, the new foundational document does not end politics. Rather it introduces new risks and trade-offs. Burkhardt points to the trade-offs inherent in future elections, and the choices Putin faces, underscoring the unavoidable risks of a geriatric personalist ruler. Smyth and Wilson Sokhey argue that Putin's renewed emphasis on social rights has a real political downside, since the promise of increased social support is rarely implemented as written. Yet, they suggest that the reforms alter the currency of electoral politics, placing social welfare, and not political or civic rights, at the center of state-society contestation. Goode adds that the reflection and mobilization of everyday patriotism in the amendments and national vote reveals the limits of the Kremlin's brand of patriotism, highlighting persistent friction between state and society.

The authors agree that the Russian state has proven remarkably durable in the face of exogenous shocks and homegrown challenges, but they suggest that these problems are often kicked down the road rather than solved. It remains unclear how this dynamic of accumulation will affect stability over time. As Gel'man concludes, these changes may limit disasters, but they are also likely to "aggravate the vices of bad governance". This pattern is not a winning formula for a stable constitutional order and only delays (for how long no one knows) the next reckoning with Russia's highest law. 